\title{
FOGYASZTÓI ELLENÁLLÁSRA VALÓ AFFINITÁS A MAGYAR FOGYASZTÓK KÖRÉBEN
}

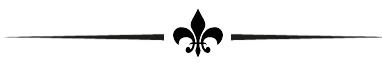

\section{AFFINITY FOR CONSUMER RESISTANCE AMONG HUNGARIAN CONSUMERS}

\author{
- \\ JAKOPÁNECZ, EsZter \\ 10 \\ Pécsi Tudományegyetem Közgazdaságtudományi Kar Gazdálkodástani Doktori Iskola \\ (University of Pécs Faculty of Business and Economics Doctoral School in Business Administration) \\ H - 7622, Pécs, Rákóczi út 80. \\ e-mail: jakopaneczeszti@gmail.com
}

\begin{abstract}
sil
The causes of the loss of market results go beyond the realities of intense and noisy competition. The rejecting attitude and resistant behaviour of consumers can exert pressure on the companies' business processes - several market examples draw attention to the weight of those consequences. To find out the appropriate way to handle this phenomenon became inevitable. The resistant behaviour of consumers exists in numerous markets and industries, among these foods are particularly concerned. There are examples for short and long term, but intense consumer indignation. Although consumer resistance is not a product- or market-specific phenomenon, it's worth considering the issue of food, because of its embeddedness in everyday life, so market players may face easily criticism and conflict of interest. The study provides an overview of markets facing consumer resistance. The aim of the quantitative research is to find out the affinity of Hungarian consumers for consumer resistance and its various forms.
\end{abstract}

KuLCSSZAVAK: fogyasztói magatartás, fogyasztói ellenállás, aktív fogyasztói ellenállás, nemvásárlás
KEYWORDS: consumer behaviour, consumer resistance, active consumer resistance, non-buying

\section{BEVEZETÉS - INTRODUCTION}

A fogyasztói magatartás terén jelentős változásokat tapasztaltunk az elmúlt években, évtizedekben. A fogyasztói gondolkodás és magatartás egyre kiszámíthatatlanabb lett, amit a 2008-as évtől a gazdasági válság is új motívumokkal tarkított. Fogyasztói magatartással foglalkozó kutatók szerint mára a fogyasztó nehezebben követhető, érthető és megszólítható (HOCHMAN, 2010; TÖRÖCSIK, 2011; LÁSZLÓ és FÖLDI, 2013). E változások mögött kétségkívül szerepet játszik a piaci környezeti tényezők okozta bizonytalanság, illetve emellett a fogyasztói tudatosság erősödésének is tanúi vagyunk. Ez utóbbit támasztja alá, hogy például az egészségtudatosság és táplálkozás kérdéskörében egyre több kutatás készül hazánkban is (DÖRNYEI, 2010; NEULINGER és
SIMON, 2011; SZENTE, SZAKÁLY és SZÉLES, 2011; LEHOTA, CSÍKNÉ MÁCSAI és RÁCZ, 2013; SZAKÁLY et al., 2014; illetve BRÁVÁCZ, 2015).

Jelen tanulmány a fogyasztói magatartás sajátos esetére hívja fel a figyelmet: a fogyasztók vállalati gyakorlatot és törekvéseket akadályozó magatartására, a fogyasztói ellenállásra. Karakteres vonása, hogy olyan jószágok, vállalatok, piacok állnak a középpontjában, amelyek termékük, szolgáltatásuk, múködésük valamely tulajdonsága révén a fogyasztók bizonyos csoportjából negatív beállítottságot, illetve passzív és/vagy aktív elutasítást, szembenállást váltanak ki. Történik ez annak ellenére, hogy e termékek, vállalatok, piacok alapvetően a fogyasztók reális igényeit célozzák meg. A célkeresztbe kerülő tulajdonságok értékelése során az emberekben erős negatív érzelmek 
keletkeznek, gyakran félelem is. Az értékelés fókuszába kerülő attribútumokat az egyes érdekcsoportok jellemzően teljesen ellentétes minőségben ítélik meg, vitát generálva azok teljesítményéről, alkalmazhatóságáról, jóságáról, illetve rövidebb vagy hosszabb távú hatásairól.

A passzív vagy aktív módon megnyilvánuló fogyasztói elutasítottság korlátozza a jószágok széles körben elterjedését, ezáltal a piaci szereplők veszteséget és versenyhátrányt szenvednek, esetleg a piacról való kivonulás is bekövetkezhet. Kiemelendő, hogy a fogyasztói ellenállás túlmutat az innovációk piaci elfogadásának folyamatán. A szakirodalom ismeretei és a megfigyelhető piaci példák szerint bármely piacon releváns problémát okozhat, illetve a termékek/piacok életciklusának bármely szakaszában kialakulhat.

A fogyasztókban kialakuló negatív érzések, illetve félelem több forrásból táplálkozhat: tudáshiányból, információk hiányából, az újdonságtól vagy változástól való félelemből, a termékkel kapcsolatos tapasztalatok hiányából, az emberre/környezetre valamilyen feltételezett/ bizonyított káros hatás vélelmezéséből, illetve a hosszú távú következmények becslési korlátaiból. Az elutasító piaci környezet kialakulásához a fogyasztókon kívül más piaci résztvevők, például civil mozgalmak, ellenérdekeltek, kormányzati tisztségviselők tevékenysége is hozzájárulhat. A célpont is sokféle lehet: vonatkozhat kifejezetten jószág(ok)ra, vállalati termelési folyamat(ok)ra, vagy akár egy adott vállalat egészére.

Egy ilyen megváltozott piaci környezetben adott szervezet nem csak az elutasítás, a kialakult félelmek feloldása kapcsán szembesül kihívásokkal. A (vonzó) termékelőnyök hangsúlyozása sem hozza az elvárásokat, vagyis a korábban eredményekkel alkalmazott marketingeszközök hatástalanokká válnak.

A fogyasztói ellenállás témakörében az élelmiszerek és az élelmiszeripar érintettségét érdemes kiemelten vizsgálni. Mivel az élelmiszeripari termékek és szolgáltatások az emberek hétköznapi életébe szorosan beágyazottan vannak jelen, ezért az esetlegesen felmerülő aggályok révén könnyen kerülhetnek a figyelem középpontjába, közvetlen reakciókat kiváltva a fogyasztókból.

\section{IRODALMI ÁTTEKINTÉS -}

\section{LITERATURE REVIEW}

A fogyasztói ellenállás jelenségét széles szakirodalmi bázison tárgyalják a szakirodalomban, elsősorban külföldi kutatók munkái nyomán. Az alábbiakban a jelenség potenciáljára, az érintett piacokra, a fogyasztói ellenállás esetek sajátosságaira irányítjuk a figyelmet. A megfigyelhető piacok kapcsán a fogyasztói ellenállás kifejeződésének mértéke, illetve ennek piaci következményeinek súlya hívja fel elsődlegesen a figyelmet arra, hogy a fogyasztói ellenállás problematikája a releváns marketing kérdéskörök közé tartozik.

Szükséges leszögezni, hogy a fogyasztói ellenállás nem újkeletű jelenség. A fogyasztói ellenállás már az 1980-as években felkeltette a szakma figyelmét. Az eltelt idő alatt a témával kapcsolatban széles körü ismeretek kerültek kidolgozásra nemzetközi szinten. Az elsők között az innovációk kapcsán tapasztalható fogyasztói ellenállással kezdtek el foglalkozni (SHETH, 1981; RAM, 1987). E kérdéskör közel három évtized távlatából sem veszített aktualitásából, a vállalatok a mai napig szembesülnek veszteségekkel az innovációk kedvezőtlen piaci fogadtatásából fakadóan (GARCIA, 2007; KLEIJNEN, LEE és WETZELS, 2009). Az elmúlt időszakban főleg kiemelt piacra, technológiára fókuszálnak a vizsgálatok. Ezek között a gén- és biotechnológia lakossági elutasítottsága népszerű kutatási terület: Németországban többek között WILLERS (2007) foglalkozott kiemelten a témával, a hazai helyzetre MATOLAY (2012) adott betekintést. Az atomenergia is sokakat foglalkoztat, itthon KOVÁCS (2010) tárta fel a hazai viszonyokat. Az innovációkkal szembeni fogyasztói ellenállás piaci relevanciáját mutatja az is, hogy az 1960-as évektől a diffuziós elméletek marketingszempontú vizsgálatát a kereskedelmi gyártócégek maguk szervezték, de legalábbis egyetemi professzorokkal való együttmúködés keretében szponzorálták azokat (ROGERS, 1976).

Kiemelendő, hogy e jelenség nem korlátozódik az innovációkra. Kisebb vagy nagyobb mértékben aggályokat generálnak a sokszor érthetetlen módon múködő technikai fejlesztések, mint például a mikrohullámú sütő és a különböző elektromos készülékek. Állatvé- 
delmi aggályok is felmerülnek egyes iparágakkal szemben, mint a kozmetikai iparban alkalmazott állatkísérletek kapcsán is, amelyek betiltásáról Európai Uniós szinten hoztak szabályokat (EURÓPAI BIZOTTSÁG, 2013). $\mathrm{Az}$ abortusz tabletták bevezetését is nagy társadalmi ellenállás kísérte. Szerveződtek és szerveződnek ellenállási mozgalmak, karakteres véleménynyilvánítások a McDonald's-szal, a McDonaldizációval és amerikanizációval (RITZER, 1983) szemben is, hatást gyakorolva a cég piaci gyakorlatára is. A nyomásgyakorlók között példaként említhetjük a LONDON GREENPEACE 1986-os akcióját, illetve az 1987-ben indult olaszországi Slow Food mozgalom 2000-es éveket megelőző időszakát ${ }^{1}$ (SASSATELLI és DAVOLIO, 2010; lásd még RITZER, 1983). Ma már nem csak élelmiszeripari és olajipari szereplőket érik kritikák, a divatipart is megszólították: történnek törekvések abba az irányba, nem kevés sikerrel, hogy a nagy divatmárkák gyártási folyamatait fogyasztói nyomásgyakorlással tegyék a környezetre és az emberre kevésbé ártalmassá, illetve fair-ré (GREENPEACE, 2014). Továbbá olyan témakörök is érintettek, amelyek e fenti mainstream témákhoz képest a köztudatba szinte el sem jutottak: például az élelmiszerbesugárzás mint tartósítási módszer a fogyasztók elutasítottsága miatt nem tudott elterjedni az élelmiszeriparban (BÁNÁTI, 2007).

Hazánkban is történtek fogyasztói ellenállási esetek, amelyek mind az adott szakma, mind a laikusok figyelmét intenzíven felkeltették. A H1N1 influenzavírus elterjedése idején az ellene védőoltást adó vakcinát a lakosság magas arányban elutasította (TÖRŐCSIK és JAKOPÁNECZ, 2010). Kifejezetten hazai példa az osztrák Négy Mancs civil állatvédő szervezet esete, amely a magyarországi hagyományos libatöméses és -tartási eljárásokkal szemben lépett fel, jelentősen korlátozva a hazai vállalatok exportlehetőségeit (TÖRŐCSIK, JAKOPÁNECZ és SOÓS, 2011; FODOR és TÓTH, 2013). A génmódosított élelmiszerek és vetőmagok hazai alkalmazásának tiltása évek óta aktuális kérdés. Az atomenergia kérdéskörében a magyar lakosságnak látszólag nincs hatása a piaci folyamatokra. Időről időre azonban készülnek olyan értekezések, elemzések, amelyek a hazai energiafogyasztók beállítottságát mérik, kimutatva az atomenergia meglehetősen nagyfokú elutasítottságát (KOVÁCS, 2010; TÖRÖCSIK és JAKOPÁNECZ, 2011; IPSOS GLOBAL ADVISORY, 2011; ATOMEROMU, 2013).

A piaci példák sokaságát és változatosságát figyelembe véve felmerül a kérdés, milyen módon lehet, illetve érdemes a fogyasztói ellenállással szembesülő piacokat osztályozni, rendszerezni. Az alábbi, 1. ábra egy lehetséges tipológiát mutat be, amely az ellenállás/szembenállás intenzitásának mértéke, illetve annak időbeli kiterjedtsége alapján csoportosítja a piaci eseteket.

$\mathrm{Az}$ atomenergia kapcsán egészen világosan látszik a technológia „életútja”. A hosszú évek során a használat elterjedése mellet elutasított, de el nem tûnő technológiának tekinthető - aminek kapcsán a társadalom széles körű szembenállása is kimutatható. Az eset felhívja a figyelmet, hogy a hosszabb távon heves vitákat kiváltó kérdések egyes esetekben nem tünnek el a társadalmakból, és az ellentétek ellenére kell együtt élnünk velük.

A megbotránkoztató termékek sajátja, hogy a média és közbeszéd előterében csak rövidebb ideig tartózkodnak, ugyanakkor intenzív felháborodást váltanak ki széles tömegekből. E témák közös pontja többnyire az emberi egészség és az élelmiszerlánc, illetve ez utóbbi biztonsága, bizonytalansága, kockázatai. Vannak esetek, amelyek kifejezetten 'média-lufiként' viselkednek: ezek kapcsán a félelmek, aggodalmak keltéséhez a média aktivitása nagy mértékben hozzájárul - ennek magas intenzitása a figyelem konstans magas szinten való tartását is eredményezi.

Az 1. ábrán feltüntetett etikai kérdések csoportja olyan témákat foglal magában, amelyek kevéssé egészségi, sokkal inkább jogi, illetve etikai, erkölcsi kérdéseket vetnek fel.

A tartós konfliktusként azonosított mikrohullámú sütő és mobiltelefon példája két olyan eszközt emel ki, amelyek pozitív hozadékai egyértelmüen felülmúlják a negatív hatásokat és a felmerülő bizonytalanságokat, kockázatokat.

\footnotetext{
${ }^{1}$ Az olaszországi Slow Food mozgalom céljai a fenntarthatósági és ökológiai elvek erősödése hatására a 20oo-es évek után az öko-gasztronómia koncepciója felé tolódott (SASSATELLI és DAVOLIO, 2010).
} 
A klasszifikációt nehezíti, hogy az egyes eseteket nem könnyü besorolni: egyrészt azért, mert más és más fogyasztói csoportok érintettek az egyes kérdésekben, másrészt pedig, mert a jövőbeli alakulásuk becslése is korlátos. HAMPEL és munkatársai (1998) meglátása szerint a fogyasztói ellenállás előrejelezhetőségét nehezíti, hogy az egyes, látszólag kapcsolódás nélküli piaci esetek hatnak egymásra: a géntechnológiával kapcsolatos vitákat az atomenergia körüli balesetek is felerősítik.

Ha az értékelési dimenziókban meg is tudnánk egyezni, az ugyancsak további dilemmákat okozhat, hogy a fogyasztói ellenállást kiváltó piacok lehatárolása sem mindig egyér- telmü. CLAUDY és szerzőtársai (2010) szerint gyakran elutasított innovációként azonosítják a fenntarthatósággal és alacsony szénhidrogén kibocsátással jellemezhető zöld technológia alkalmazását is.

A fentiek azt mutatják, hogy fogyasztói ellenállással fóleg azokon a területeken találkozunk, ahol a fogyasztó elveszíti kontrollját, rálátását az egyes piaci folyamatokra. Azok az esetek is kiemelkednek, amelyeken a fogyasztó tudása elégtelennek bizonyul a piaci kínálati elemekről való megalapozott döntéshez. Átgondolásra érdemes kiemelni a géntechnológia esetét.

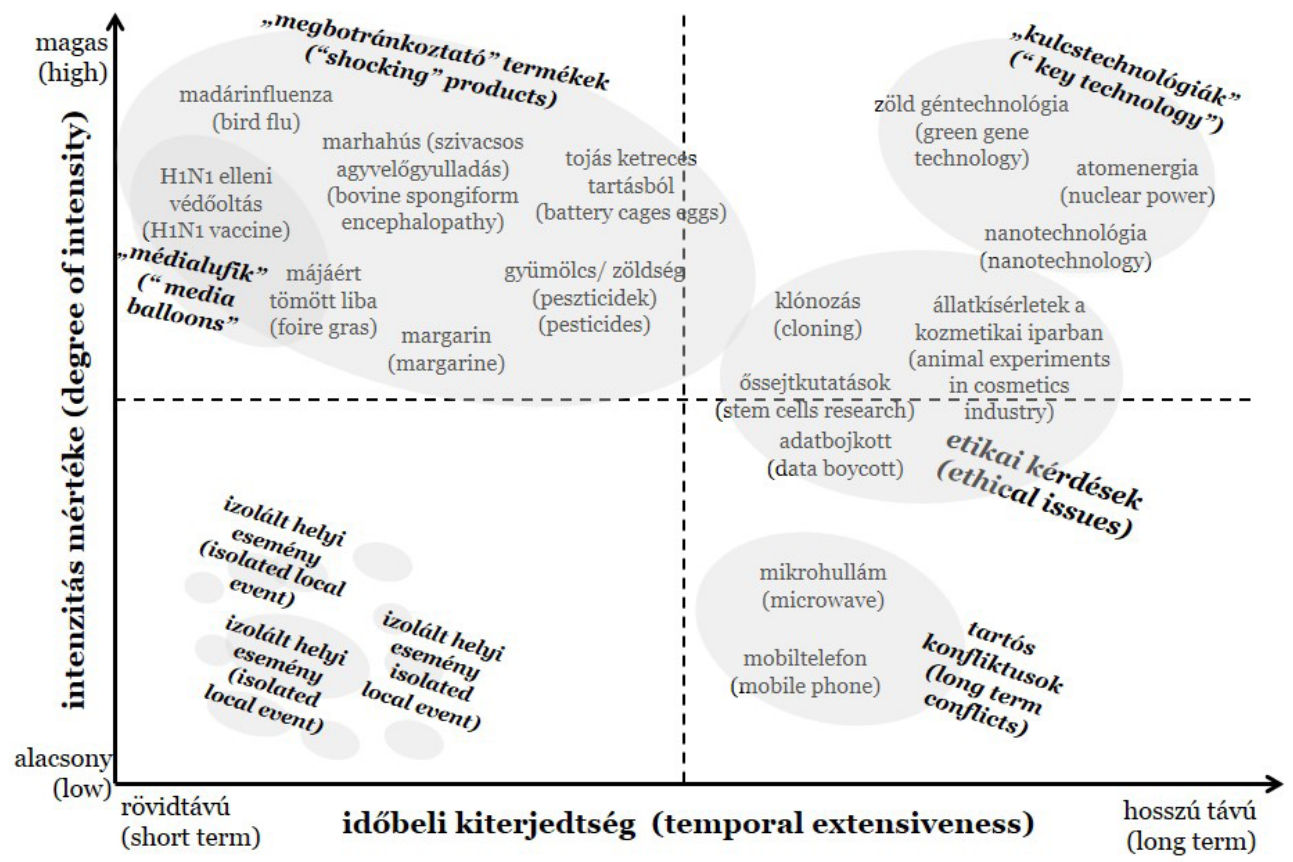

1. ÁBRA

\section{Fogyasztói ellenállást kiváltó piaci esetek tipológiája (Tipology of Consumer Resistance Cases)}

Forrás (Source): WILLERS, 2007, 117. o. alapján (Based on WILLERS, 2007, 117. p.) 
A kapcsolódó ellenállást az embert és környezetet érintő, korlátozottan becsülhető hosszú távú következmények bizonytalansága alapozza meg. Ez arra hívja fel a figyelmet, hogy e technológia piacának fejlődését a kockázat érzékelése, az általa kiváltott félelem nagymértékben gátolja, lassítja (KOPPELMANN és WILLERS, 2008). Egyes szerzók az információs aszimmetria jelenségére helyezik a súlyt, ami ugyancsak növelheti a bizonytalanságot, bizalmatlanságot a fogyasztók körében (HUFFMAN et al., 2003). A génmanipulált növények és élelmiszerek piacát is meghatározzák ezek a körülmények. A piaci folyamatokat meghatározó biotechnológiai vállalatok és környezetvédő szervezetek egymásnak ellentmondó állításokkal jelennek meg a médiában, a fogyasztók pedig csak ezen, gyakran ellentétes állításokon alapuló információkra tudnak hagyatkozni a vásárlási, fogyasztási döntéseik során - saját tapasztalat híján. Az értékelési döntést nehezíti, hogy mindkét oldalon szakértők, és nem laikusok közvetítik az üzeneteket a fogyasztók szélesebb rétegei felé.

A következő fejezetben a magyar fogyasztók körében végzett empirikus kutatás eredményeit tekintjük át, amelynek keretében a fogyasztói ellenállásra való affinitást vizsgáljuk egy 1516 főt magában foglaló, országos reprezentatív kutatás keretében.

\section{ANYAg ÉS MÓDSZER - MATERIAL AND METHOD}

A magyar fogyasztók körében országos reprezentatív felmérés keretében két témakör került vizsgálatra:

- a fogyasztók ellenállásra való affinitása, jellemző reakcióik;

- egyes, potenciálisan ellenállást kiváltó területek fogyasztói megítélése, érintettsége.

E kérdéskörök vizsgálatára kvantitatív kutatás valósult meg 2014 decemberében, a TÁMOP-4.2.2.A-11/1/KONV-2012-0058 Energiatermelési, energiafelhasználási és hulladékgazdálkodási technológiák vállalati versenyképességi, városi és regionális hatása- inak komplex vizsgálata és modellezése címü projekt keretében. A megkérdezésben 1516 fő vett részt a 18-69 éves korosztályból. A minta reprezentálja a célcsoportot a $\mathrm{KSH}$ irányadó statisztikáinak megfelelően a következő ismérvek mentén: nem, korcsoportok, legmagasabb befejezett iskolai végzettség, lakóhely településtípusa, lakóhely régióban elfoglalt helye. A megkérdezettek demográfiai jellemzőit az 1. táblázat számszerüsíti.

Az elemzési munkát IBM SPSS Statistics 20.0, illetve Microsoft Office Excel 2007 programokkal végeztem. Az alábbiakban bemutatott eredmények egyváltozós és többváltozós (keresztábla- és klaszterelemzés) módszerek során jöttek létre. A háttérelemzések és a többváltozós elemzések eredményeként azok az adatok kerülnek bemutatásra, amelyek szignifikánsak 5\%-os szint mellett.

\section{EREDMÉNYEK - RESUlts}

A felnőtt lakosság körében a fogyasztói ellenállás és tudatosság relevanciáját négy kérdés segítségével vizsgáltam. A kérdéseket és az eredményeket a 2. táblázat részletezi.

A legmagasabb átlagos értékelést annak kapcsán adták a válaszadók, miként látják a fogyasztók tudatosságának változását ma, illetve a következő évekre (átlagok: 6,72 és 7,09). Ez alapján bizakodónak értékelhetjük a fogyasztókat. A fogyasztói összefogás erejében való hitük ugyancsak pozitív, bár ennél mérsékeltebb. A magyar fogyasztók negatív véleményének kifejezése kapcsán pozitív oldalra billent a mérleg, bár határozottnak semmiképp sem értékelhető az 5,7 körüli átlag. A tudatosság változásának kérdései mutatják a legalacsonyabb szórást és relatív szórást is, vagyis a válaszok ezek esetében térnek el átlagosan legkevésbé a mintaátlagtól, illetve ezek esetében jellemző a válaszadókra leginkább a mintaátlag. Tehát a megkérdezettek a tudatosság kérdésében mutatnak leginkább hasonló véleményeket, legkevésbé pedig a negatív vélemények felvállalása terén. 
JAKOPÁNECZ, E.

A minta bemutatása

(Introduction of the Sample)

$(N=1516)^{2}$

\begin{tabular}{|c|c|c|}
\hline Demográfiai csoportok (Demographic Groups) & $\mathbf{N}$ & $\%$ \\
\hline \multicolumn{3}{|l|}{ Nemek szerint (Gender) } \\
\hline Férfi (Men) & 747 & 49,3 \\
\hline Nő (Women) & 769 & 50,7 \\
\hline \multicolumn{3}{|l|}{ Korcsoportok (Age Groups) } \\
\hline 18-29 éves (18-29 years) & 248 & 16,4 \\
\hline 30-39 éves (30-39 years) & 397 & 26,2 \\
\hline 40-49 éves ( $40-49$ years) & 314 & 20,7 \\
\hline $50-59$ éves ( $50-59$ years) & 287 & 18,9 \\
\hline 6o-69 évesek (6o-69 years) & 270 & 17,8 \\
\hline \multicolumn{3}{|c|}{ Iskolai végzettség szerint (Qualification) } \\
\hline 8 általános (Elementary School) & 87 & 5,7 \\
\hline Szakmunkásképző (Vocational School) & 391 & 25,8 \\
\hline Érettségi (High School Degree) & 792 & 52,2 \\
\hline Felsőfokú végzettség (University Degree) & 246 & 16,2 \\
\hline \multicolumn{3}{|c|}{ Lakóhely településtípusa (Country Seat) } \\
\hline Budapest (Budapest) & 263 & 17,3 \\
\hline Megyei jogú város, megyeszékhely (City of County) & 275 & 18,1 \\
\hline Egyéb, 10.000 fősnél nagyobb város $(10.000+$ Settlement) & 325 & 21,4 \\
\hline 10.0oo fősnél kisebb város (Settlement under 10.0oo) & 200 & 13,2 \\
\hline Falu, község (Village) & 453 & 29,9 \\
\hline \multicolumn{3}{|c|}{ Lakóhely régióban elfoglalt helye (Region) } \\
\hline Közép-Magyarország (Central Hungary) & 192 & 12,7 \\
\hline Közép-Dunántúl (Central Transdanubia) & 170 & 11,2 \\
\hline Nyugat-Dunántúl (Western Transdanubia) & 160 & 10,6 \\
\hline Dél-Dunántúl (Southern Transdanubia) & 139 & 9,2 \\
\hline Észak-Magyarország (Northern Hungary) & 192 & 12,7 \\
\hline Észak-Alföld (Northern Great Plain) & 209 & 13,8 \\
\hline Dél-Alföld (Southern Great Plain) & 191 & 12,6 \\
\hline Budapest (Budapest) & 263 & 17,3 \\
\hline \multicolumn{3}{|c|}{ Szubjektív jövedelmi helyzet (Perceived Income Level) } \\
\hline Átlag alatti (Below the Average) & 670 & 44,2 \\
\hline Átlagos (Average) & 677 & 44,7 \\
\hline Átlag feletti (Over the Average) & 114 & 7,5 \\
\hline NT/NV (N.A.) & 55 & 3,6 \\
\hline
\end{tabular}

${ }^{2}$ A minta tervezésekor legalább 1500 fő megkérdezését céloztuk meg, az erre elkülönített költségvetés azonban valamivel nagyobb megkérdezetti kör elérését tette lehetővé. 
Kérdések a fogyasztói ellenállásra való affinitás mérésére (Questions to Measure the Affinity for Consumer Resistance)

$(N=1516)$

\begin{tabular}{|c|c|c|c|c|c|}
\hline \multirow[b]{2}{*}{$\begin{array}{c}\text { Kérdések } \\
\text { (Questions) }\end{array}$} & \multicolumn{5}{|c|}{$\begin{array}{c}\text { Statisztikai mutató } \\
\text { (Statistical Indicator) }\end{array}$} \\
\hline & Min & $\operatorname{Max}$ & $\begin{array}{c}\text { Átlag } \\
\text { (Mean) }\end{array}$ & $\begin{array}{l}\text { Szórás } \\
\text { (Standard } \\
\text { Deviation) }\end{array}$ & $\begin{array}{c}\text { Relatív } \\
\text { Szórás, } \\
\text { (Coefficien } \\
\text { of } \\
\text { Variation) }\end{array}$ \\
\hline
\end{tabular}

k1: Hisz-e abban, hogy a fogyasztók összefogással hatást tudnak gyakorolni a vállalatok tevékenységére? (1 - egyáltalán nem; 10 - nagyon) (Do you believe that consumers can influence companies' activities with the power of unity? (1 - Not at all; 10 - Extremely))

k2: Mit gondol, milyen mértékben vállalják a fogyasztók ma Magyarországon azt, hogy kifejezzék valamely vállalat termékével vagy tevékenységével kapcsolatosan a negatív véleményüket, elutasításukat? (1 - egyáltalán nem; 10 - határozottan)

$1 \quad 10 \quad 6,38 \quad 2,388$

0,374

(To what extent do you think, consumers in Hungary undertake today to express their negative opinions or rejections towards companies' products or activities? (1 - Not at all; 10 - Firmly))

k3a: Milyen változást lát a fogyasztók tudatosságában az 5 évvel korábbiakhoz képest? (1 sokkal kevésbé; 10 - sokkal tudatosabbak) (What changes do you see in consumers' consciousness today compared to 5 years ago? (1 - Much less; 10 - Much more conscious))

$\begin{array}{lllll}1 & 10 & 5,68 & 2,282 & 0,402\end{array}$

k3b: Milyen változást lát a fogyasztók tudatosságában a következő 5 évben a mai helyzethez képest? (1 - sokkal kevésbé; 10 - sokkal tudatossabbak) (What changes do you see in consumers' consciousness in the next 5 years?

$\begin{array}{lllll}1 & 10 & 6,72 & 1,990 & 0,296\end{array}$
(1 - Much less; 10 - Much more conscious)) 
A kutatás kitért arra is, milyen reakciókat váltana ki a válaszadókból, ha egy vállalat felháborodást keltene bennük. A válaszlehetőségek megoszlását a 3. táblázat összegzi.

A legtöbb válaszadó felháborodás esetén nem vásárolná a vállalat termékeit, szolgáltatásait - ezt közel 81\% jelölte meg. Szintén magas arányban vannak, akik elmondanák ismerőseiknek, családtagjaiknak az esetet. A közösségi média adta lehetőségek között a legtöbben azt jelezték, hogy megosztanák felháborodásukat másokkal. Ahhoz már csak szúkebb kör folyamodna, hogy a vásárlás elutasítására buzdítson másokat a közösségi média felületein. Közel $13 \%$ jelezte, hogy petíciót írna alá, további $6 \%$ pedig tüntetésen (is) részt venne.

A magyar fogyasztók fogyasztói ellenállásra való affinitásának mélyebb vizsgálatára klasz- terelemzést végeztem. Az eljáráshoz az alábbi kérdések standardizált formái (SIMON, 2006) kerültek felhasználásra. Az elemzés K-közepű klaszterelemzéssel történt ${ }^{3}$, amelynek eredményeként 3 klaszter került azonosításra. E csoportok a teljes mintát lefedik, a következő megoszlással:

- 1-es klaszter: 726 fó, 47,9\%;

- 2-es klaszter: 559 fö, 36,9\%;

- 3-as klaszter: 231 fö, 15,2\%.

Az iterálási folyamat ${ }^{4}$ lezártával létrejött klaszterközéppontok szolgáltattak alapot az egyes klaszterek térben elfoglalt helyének megrajzolásához, illetve támpontokat az egyes szegmensek nevesítéséhez (MALHOTRA, 2005; VARGA és SZILÁGYI, 2011). Az egyes változók a következő statisztikákkal jellemezhetőek (4. táblázat)5.

\section{TÁBLÁZAT}

TABLE 3

\section{Reakciók abban az esetben, ha egy vállalat magatartásával felháborodást vált ki (Reaction in Case of Indignation Aroused by Corporate Behavior) $(N=1516)$}

\begin{tabular}{|c|c|}
\hline Fogyasztói reakciók (Consumer Reactions) & $\%$ \\
\hline $\begin{array}{l}\text { k4_1: Nem vásárolja többet a termékét, szolgáltatását (Does not buy the company’s products } \\
\text { or services anymore) }\end{array}$ & 80,8 \\
\hline k4_2: Elmondja az ismerőseinek, családjának (Tells friends and family) & 77,8 \\
\hline k4_3: A közösségi médiában osztja meg felháborodását (Shares indignation in Social Media) & 37,1 \\
\hline $\begin{array}{l}\text { k4_4: A közösségi médiában felszólít másokat, hogy ne vásárolják a vállalat termékét, szol- } \\
\text { gáltatását (Calls for others in Social Media not to buy the company’s products or services) }\end{array}$ & 14,4 \\
\hline $\begin{array}{l}\text { k4_5: Petíciót ír alá a helytelen vállalati magatartás megszüntetéséért (Signs a petition } \\
\text { against incorrect corporate behavior) }\end{array}$ & 13,1 \\
\hline $\begin{array}{l}\text { k4_6: A közösségi médiában felszólít másokat, hogy csatlakozzanak az elutasítók táborához } \\
\text { (Recruits others in Social Media to join the group of refusers) }\end{array}$ & 11,5 \\
\hline $\begin{array}{l}\text { k4_7: Tüntetésen vesz részt, hogy nyomást gyakoroljon a vállalatra (Protests to put pressure } \\
\text { on the company) }\end{array}$ & 6,2 \\
\hline k4_8: Nem tesz semmit (Does not do anything) & 2,0 \\
\hline \multicolumn{2}{|c|}{$\begin{array}{l}\text { 3Az eljárást iterálással végeztem, amely során minden klaszterhez egy-egy középpontot rendelünk. Az iterálás folyamatában a } \\
\text { konvergencia kritériumot nullának határoztam meg, vagyis a klaszterközéppontok mindaddig változtak, míg nem volt teljes } \\
\text { egyezőség a klaszterközéppontok és az elemek között. } \\
\text { ^Az iterálási folyamat } 9 \text { lépésben zajlott. A klaszterközéppontok közötti legkisebb távolság } 8,265 \text {. } \\
{ }^{5} \mathrm{Az} \text { egyes standardizált változókhoz tartozó F értékekból azt olvashatjuk ki, hogy az aktivitási elemek jelentős különbséget } \\
\text { mutatnak a klaszterek kialakítására gyakorolt hatásukban: a legmagasabb értékeket a petíció és tüntetés kapcsán találunk, } \\
\text { vagyis ezen változók mentén a legtökéletesebb a klaszterek kialakulása, szemben a személyes szájreklámmal és a nemvásár- } \\
\text { lással, amelyek a leggyengébb hatással bírnak. Vegyük észre, hogy míg előbbi válaszok csak szúk körre, utóbbiak a megkérde- } \\
\text { zettek magas arányára jellemzőek. }\end{array}$} \\
\hline
\end{tabular}




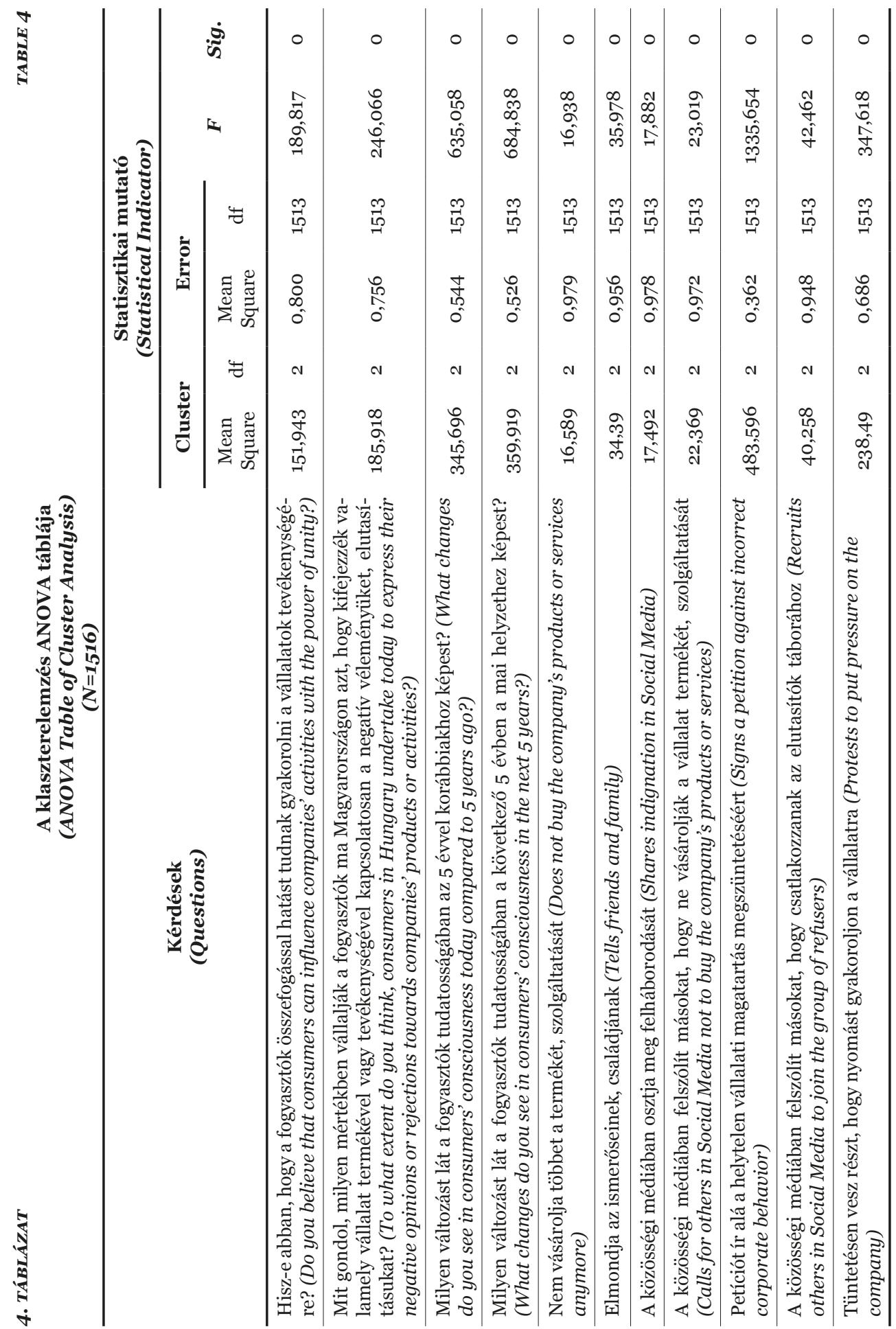


E fentiek alapján a következő szegmensek rajzolódtak ki a több mint 1500 fős országos reprezentatív lakossági mintában (2. ábra):

- Passzív optimisták (47,9\%): A csoporttagok érzékelik a legnagyobb előrelépést a fogyasztói tudatosság változásában, és ebben a kérdésben a jövőre vonatkozóan is pozitív a véleményük. Emellett a negatív vélemények felvállalását is a leginkább akadálytalannak vélik. Viszonylag magas szinten hisznek a fogyasztói összefogás erejében. Saját magatartásukban főleg a negatív szájreklámra (személyesen és online), illetve a nemvásárlásra mutatnak hajlandóságot, illetve valamelyest a közösségi média aktivitásokra. A petícióra és tüntetésre kevésbé fogékonyak.
- Hitetlenek (36,9\%): Az összefogás erejében való hitük rendkívül alacsony. A tudatosság terén nem látnak különösebb előrelépést, és a fogyasztók véleményének vállalására is alacsony szintü törekvést érzékelnek. A különböző reagálási formákra a legalacsonyabb affinitást mutatják. Ezek között a petíció és a tüntetés a leginkább periférikus.

- Aktivisták (15,2\%): A leginkább hisznek a fogyasztói összefogás erejében, bár a fogyasztók törekvéseivel és tudatosságával kapcsolatban inkább mérsékelt a véleményük. A csoport karakterét aktivitásában mutatott hajlandósága adja elsősorban: a petíciók aláírására, a tüntetésre, illetve a különböző közösségi média aktivitásokra a legnagyobb affinitást mutatják.

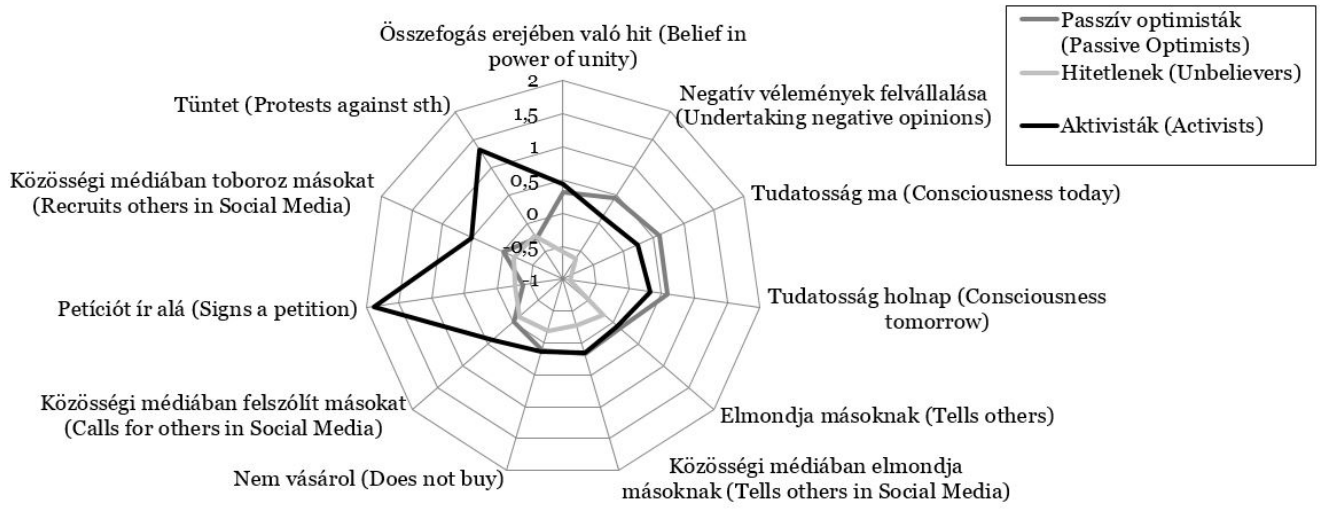

2. ÁBRA

\section{Klasztertulajdonságok a vizsgált változók alapján} (Cluster Characteristics by Examined Variables)

FIG. 2

A klaszterek karakterének pontosabb megrajzolásához demográfiai háttérelemzés készült. Az egyes demográfiai ismérvek között a következők mutatnak szignifikáns különbségeket a klaszterek között: nemek ( $\chi 2=55,523$; $\lambda=0,095, \quad \varphi=0,191, \quad$ Kramer-V=0,191; $\mathrm{p}<0,000)$, korcsoportok $\left(\chi_{2}=17,161 ; \lambda=0,002\right.$, $\varphi=0,106$, Kramer-V=0,075; $p<0,028)$, lakóhely településtípusa $(\chi 2=17,123 ; \lambda=0,000$, $\varphi=0,106$, Kramer-V=0,075; $p<0,029)$, illetve a jövedelmi helyzet szubjektív megítélése $\quad(\chi 2=20,621 ; \quad \lambda=0,033, \quad \varphi=0,117$, Kramer-V=0,082; $<<0,002)$. Az alábbi, 3. ábra azt szemlélteti, milyen mértékủ eltérést mutatnak az egyes klaszterek a teljes minta átlagához képest azon demográfiai ismérvek esetében, amelyek szignifikáns különbségeket adnak (adatok százalékpontban megadva).

A háttérelemzés szerint a passzív optimisták körében a minta átlagán felül képviseltetik magukat a nők, a 40-50 évesek, illetve az átlagos jövedelmi helyzetben élők. Átlag alatti arányban vannak körükben a vidéki, legalább 10.000 fős városok lakói.

A hitetlenek csoportjában felülreprezentáltak a férfiak, a 40-60 évesek, a vidéki, legalább 10.000 fôs városokban élők, illetve az átlag alatti jövedelmúek. A budapesti lakosok átlag alatti arányban vannak a klaszterben. 
Az aktivisták szegmensében a teljes minta átlagához képest jelentősen magasabb arány- ban vannak a férfiak, a 60 év felettiek, a fővárosban élők.

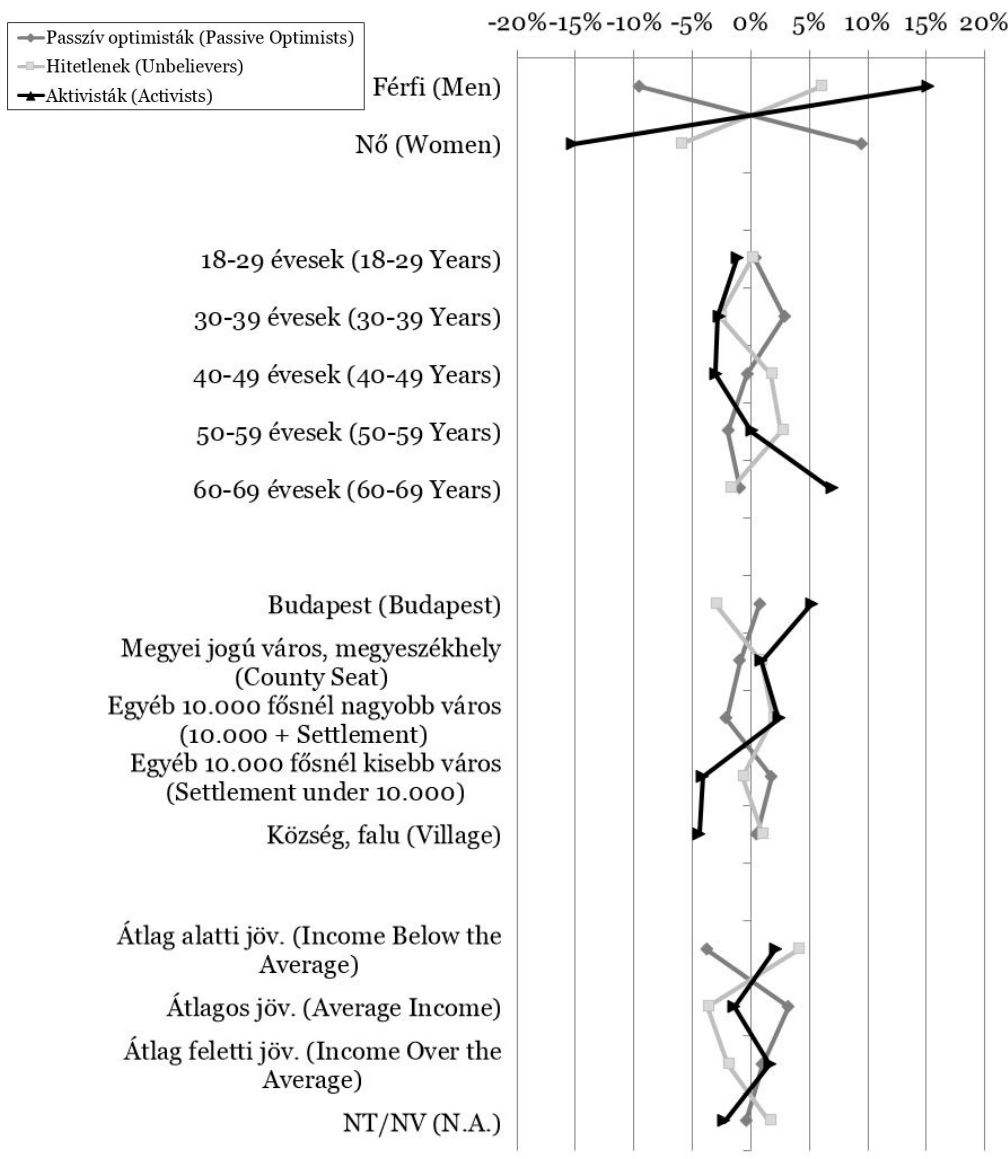

\section{3. ÁBRA}

\section{Az egyes klaszterek demográfiai profilja (Clusters' Demographic Profiles)}

Megjegyzés (Notes): Mintaátlagtól való százalékpontos eltérések. (Deviations from sample average in percent point.)

A kutatás második nagyobb témakörét 11 különböző piaci eset megítélésének vizsgálata képezte. Három kérdés vonatkozásában fejezték ki a megkérdezettek véleményüket: ismertség, érintettség, illetve utóbbi polaritása (5. táblázat).

Az eredmények alapján kiemelendő, hogy az egyes kérdésekról kialakult vélemények átlagértéke 3,0 alatti - vagyis inkább elutasítják ezeket a témákat. A libatartással és hizlalt libamájjal kapcsolatos hírek ugyan sokakhoz eljutottak, azonban csak szúk kört foglalkoztat- nak, véleményük is inkább semleges. A relatív szórás alapján az is látszik, hogy ebben a témában a leginkább egyöntetű a válaszadók értékelése. A legnagyobb elutasítást mutató témakörök között, a génmódosított élelmiszerek és a kozmetikai iparban alkalmazott állatkísérletek esetei széles körű nyilvánosságot kaptak, azonban a vélemények ebben az esetben a legkevésbé homogének. A harmadik kiemelt téma, a divatcégek káros gyártási folyamatai, jelentősen szúkebb kört érint. 


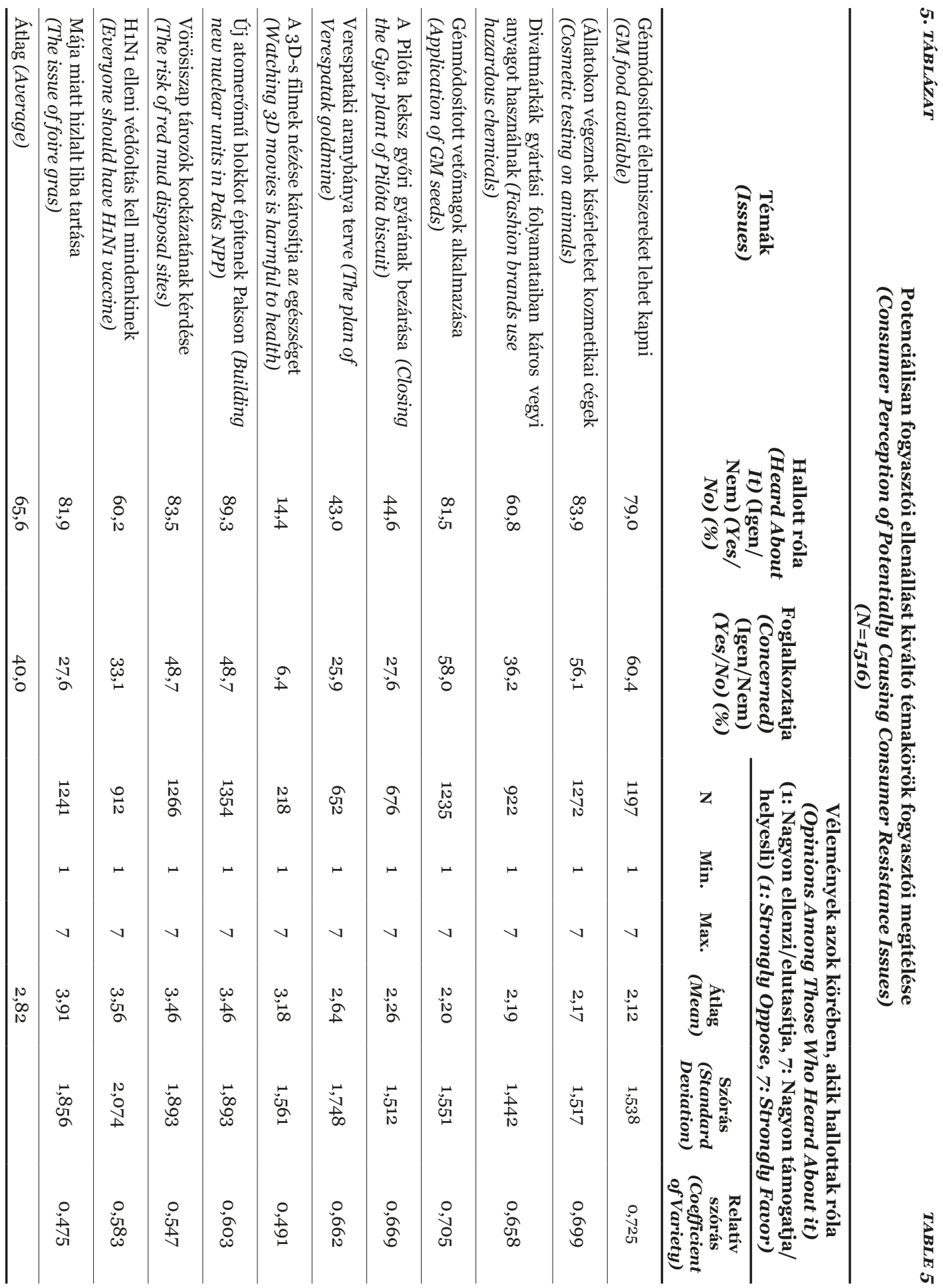


Jogosan merül fel a kérdés, vajon a fogyasztói ellenállás különböző formáiban való érintettség összefügg-e az egyes piaci esetekben való érintettséggel, bevonódással. A klaszterek összehasonlítása 4 piacon mutat szignifikáns véleménykülönbségeket (4. ábra).

A hitetlenek csoportja mind a négy esetben kitűnik azzal, hogy kevésbé ellenzőek, mint más klaszterek. A passzív optimisták a divatmárkák esetében a leginkább megengedőek, ezzel szemben leginkább elutasítóak a génmódosított élelmiszerek és a kozmetikai célú állatkísérletek témáiban. Az aktivisták a divat- márkák gyártási folyamatain háborodnak fel legintenzívebben, a génmódosított vetőmagok és állatkísérletek kapcsán azonban nem térnek el a mintaátlagtól. Mindezek azt tükrözik, hogy a vizsgált piaci esetek megítélésében a hitetlen fogyasztók csoportja tér el igazán, a passzív optimisták és aktivisták véleményében nincsenek markáns különbségek. És bár csak néhány piaci esetben szignifikánsak a klaszterek közötti eltérések, mégis figyelemreméltóak az eredmények, mivel ezek a példák egyébként a leginkább elutasítottak közé tartoznak.
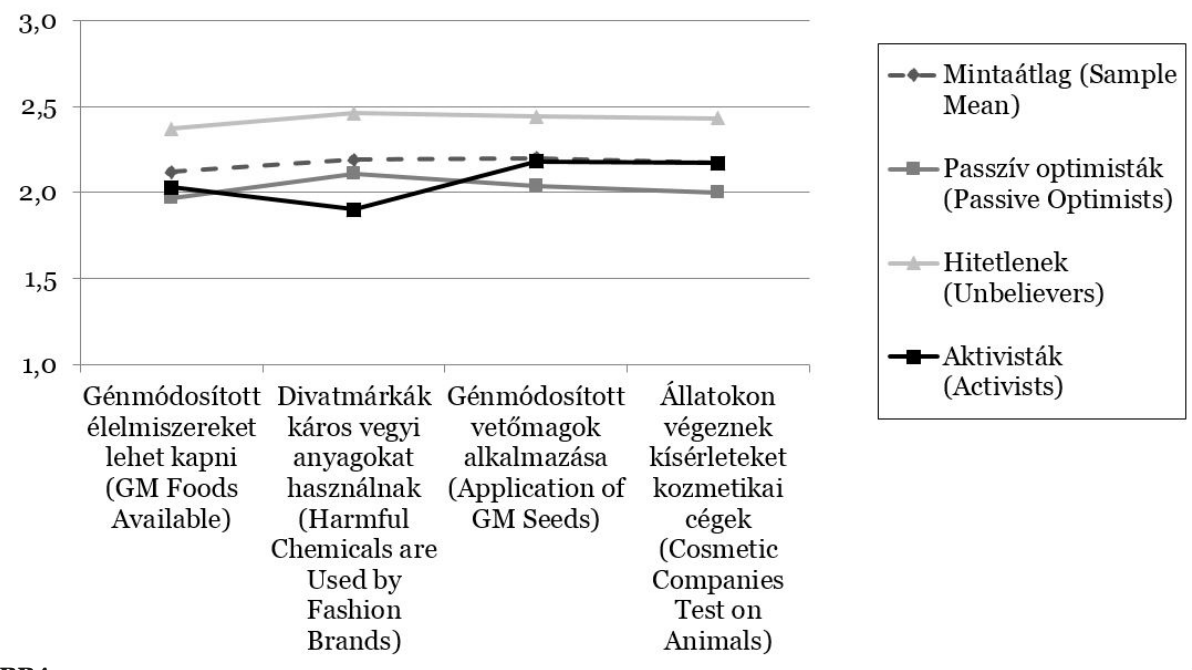

4. ÁBRA

\section{Klaszterek közötti különbségek néhány piaci eset kapcsán (Chuster Differences in Perception of Certain Issues)}

\section{KöVETKEZTETÉSEK ÉS \\ JAVASLATOK - CONCLUSIONS AND SUGGESTIONS}

A bemutatott kutatás több eredménye is figyelemre méltó a hazai marketing szakma számára. Szakirodalmi kutatások egyértelmüen felhívják a figyelmet arra, hogy az élelmiszeripar különösen releváns terület a fogyasztói ellenállás kérdéskörében. Egyes esetek ugyan rövid ideig keltik fel a fogyasztók széles körének figyelmét, ez idő alatt azonban olyan intenzív felháborodást keltenek, amelynek következményei mérhetővé válnak a cégek, piacok teljesítményében. Tovább súlyozza e témakör relevanciáját, hogy hosszú távon ható, intenzív konfliktusokat gerjesztő témaköröket is számon tartunk. A zöld géntechnológia, a biotechnológia és nanotechnológia, mint a 21. század innovációs területei, az élelmiszeripar számára nem csak lehetőséget jelentenek. Az e területeken megmutatkozó fogyasztói elutasítottság rendkívül leszűkíti a piaci lehetőségeket, illetve hatástalanná teszi az egyébként sikeres marketingeszközöket. Szükséges tehát, hogy a szakma felkészüljön és megfelelően reagáljon a fogyasztók elutasító rekcióira, etikus és a környezetért felelős gondolkodással.

A bemutatott reprezentatív kutatás eredményei szerint a megkérdezettek jelentős elmozdulást látnak ma a fogyasztói tudatosság erősödésében, és ezt várják a jövőben is. 
Ugyanakkor ki kell emelni azt is, hogy mérsékelten pozitív a beállítottságuk a fogyasztói nyomásgyakorlás terén: a negatív vélemények felvállalása, illetve az összefogás erejéban való hit kérdéseiben.

Valós problémaként értékelhetjük a fogyasztók magas arányú hajlandóságát a nemvásárlásra és a negatív szájreklámra. Valamely vállalat felháborító magatartása esetén a megkérdezettek közel 81\%-a nem vásárolná annak a termékét, illetve $78 \%$ körüli arányuk személyesen mondaná el másoknak negatív tapasztalatát. Figyelemreméltó a kimutatott klaszterek profilja és számossága: az aktív ellenálló magatartásra affin férfias csoport és az inkább paszszív, de tudatos női csoport kettőssége. Az aktív ellenállásra affin válaszadók 15,2\%-ot tesznek ki, az inkább passzív, de optimista csoport pedig 47,9\%-ot. Ez ugyancsak arra hívja fel a figyelmet, hogy a fogyasztók szélesebb rétegében inkább a passzív ellenállási formák dominálnak. Figyelemfelkeltő azonban, hogy ezek a megkérdezettek sem zárkóznak el az aktív magatartási formáktól. Felmerül tehát a kérdés, mi az a fordulópont, piaci körülmény, ami ilyen fajta reakciókat is kivált e fogyasztói körből.

Nyilvánvaló, hogy az általános beállítottságra vonatkozó eredményeket óvatosan kell kezelni olyan esetekben, ha nem állnak rendelkezésre összehasonlító adatok - akár időben, akár országok között. Segítheti azonban az értékelést, ha konkrét piacokon is vizsgálódunk. A bemutatott, 11 piaci esetre kiterjedő megkérdezés arra világít rá, hogy jelentős különbségekkel értékelik a fogyasztók az egyes piaci eseteket. Látnunk kell azonban azt is, hogy amíg egyes piacokon van választási, véleménynyilvánítási lehetősége a fogyasztóknak (például a H1N1 elleni védőoltás kapcsán), más piacokon nincs nagyon beleszólása, sem rálátása a piac folyamataira (például az atomenergia esetében).

A vizsgált esetek között a génmódosított élelmiszereket utasítják el leginkább a megkérdezettek.

Szükséges figyelembe vennünk azt is, hogy a magatartás és beállítottság között jelentős különbségek lehetnek a fogyasztói magatartásban, ahogy azt többek között az etikus fo- gyasztás kapcsán is bizonyították már a kutatók (BOULSTRIDGE és CARRIGAN, 2000; CARRINGTON et al., 2010; PELLANDINISIMÁNYI, 2014).

\section{6. ÖSSZEFOGLALÁS - SUMMARY}

A fogyasztói ellenállás a fogyasztók piaci elemeket elutasító reakciója. Kialakulásáért a bizonytalanság, félelem, ismerethiány, illetve a hosszú távú becslési korlátok miatt kialakuló negatív érzelmek felelősek elsősorban. A szakirodalom egyértelmüen a fogyasztói ellenállás jelenségének növekvő szerepére, súlyára hívja fel a figyelmet. Piaci példák sora mutatja, hogy jelentős veszteségeket okozhat a fogyasztók elutasító, szembenálló magatartása, ezért vállalatgazdálkodástani és marketing szempontból sem lehet kikerülni, hogy foglalkozzunk e témával. A bemutatott tipológiai rendszer szerint az élelmiszeripar különösen érintett a fogyasztói ellenállás kérdésében - rövid és hosszú távon érvényesülő kérdések és problémák mentén egyaránt.

A tanulmányban bemutatott, 1516 fő részvételével, reprezentatív mintán végzett online kutatás hiánypótló a hazai szakmában abban az értelemben, hogy átfogó képet ad a magyar felnőtt lakosság fogyasztói ellenállásra való affinitásáról. Ennek keretében vizsgáltam a lakosság fogyasztói ellenállással kapcsolatos általános beállítottságát, valamilyen felháborodás esetén az elképzelhető reakcióit. A megkérdezés konkrét piacokkal kapcsolatos érintettséget is mért, mégpedig 11 különböző, potenciálisan fogyasztói ellenállást kiváltó eset kapcsán. Ezek több iparágat érintenek: energiaszektor, egészségügy, élelmiszeripar, mezőgazdaság, divatipar, szórakoztató ipar, szépségipar.

Az eredmények arra mutatnak rá, hogy aktív ellenállásra a felnőtt fogyasztók viszonylag szúk rétege, 15,2\%-a mutat erős affinitást. Ez a csoport viszonylag jól lehatárolható demográfiai karakterrel jellemezhető. Emellett azonosítottam egy passzív módon reagáló, azonban optimista csoportot, amely a nemvásárlás és a negatív szájreklám eszközeire mutat erős affinitást. Figyelemre méltó azonban, hogy a meg- 
kérdezettek túlnyomó többsége (98\%) reagálna valamilyen módon egy esetleges felháborodást követően.

A piaci példák vizsgálata szerint a megkérdezettek rendkívül eltérő körben és mértékben érintettek az egyes kérdések kapcsán, változatos fogyasztói rétegeket érintve. Figyelemreméltó, hogy a vizsgált piacok között a leg-

\section{IRODALOMJEGYZÉK - REFERENCES}

\section{Atomerơmú: $\mathrm{Az}$ atomerőmű lakossági megítélése. 2013. URL: http:// www.atomeromu.hu/hu/Rolunk/ $\mathrm{Hirek} / \mathrm{transzparencia/Lapok/}$ TranszparenciaReszletek.aspx?hirId $=40$ (Letöltés dátuma: 2015. okt. 26.)}

Bánáti D.: A genetikailag módosított élelmiszerek megítélése Magyarországon és az Európai Unióban. In: Magyar Tudomány. 2007. 4 437-444.

Boulstridge, E. - Carrigan, M.: Do consumers really care about corporate responsibility Highlighting the attitude-behaviour gap. In: Journal of Communication Management. 2000. 4 (4) 355-368.

Brávácz I.: Az élelmiszerfogyasztói magatartás két dimenziója: az egészségés a környezettudatosság. Doktori értekezés. Gödöllő, SZIE Gazdálkodás és Szervezéstudományok Doktori Iskola, 2015.

Claudy, M. - O'Driscoll, A. - Garcia, R. - Mullen, M.: Consumer Resistance to Green Innovations. Developing a New Scale and an Underlying Framework. Conference Paper. 35th Macromarketing Conference. Wyoming, 2010.

Dörnyei K.: Fogyasztói magatartásvizsgálatok az élelmiszeren található információtartalomról - a jelölések, címkék és label használatának elemzése. In: Marketing \& Menedzsment. The Hungarian Journal of Marketing and Management. 2010. 44 (4) 26-34.

Európai Bizottság: Hatályba lép a kozmetikai célú állatkísérletek teljes uniós tilalma. Sajtóközlemény. Brüsszel, 2013. márc. 11. nagyobb szintű elutasítást egy élelmiszeripari téma, a génmódosított élelmiszerek váltják ki a megkérdezettekből. Ahhoz, hogy e piacok megítéléséről mélyebb ismereteink legyenek, további kutatások szükségesek, amelyek során konkrét piaci esetekre fókuszáló vizsgálatot is célszerű végezni.

Fodor R. - Tóth I. J.: A Négy Mancs kampányának gazdasági vonatkozásai. In: Marketing \& Menedzsment. The Hungarian Journal of Marketing and Management. 2013. 47 (2) 63-73.

Garcia, R.: Co-opetition for the Diffusion of Resistant Innovations: A Case Study in the Global Wine Industry using an Agent-based Model. 25th International Conference of the System Dynamics Society and 5oth Anniversay Celebration. Boston, Massachusetts, USA, July 29. Aug. 2. 2007.

Greenpeace: A Little Story about a Fashionable Lie. Greenpeace, Amsterdam, 2014.

Hampel, J. - Ruhrmann, G. - Kohring, M - Goerke, A.: Germany. In: Biotechnology in the Public Sphare. (Eds.: Durant, J. - Bauer, M. W. - Gaskell, G. A.) A European Sourcebook. Science Museum, London, 1998. 2-76.

Hochman, L.: A fogyasztóra hangolva. Akadémiai Kiadó, Budapest, 2010.

Huffman, W. E. - Rousu, M. S. - Jason F. - Tegene, A.: Consumers resistance to genetically modified foods in high income countries: the role of information in an uncertain environment. 25th International Conference of Agricultural Economists (IAAE). Durban, South Africa, 22. Aug. 2003.

Ipsos Global Advisory: Sharp World Wide Drop in Support for Nuclear Energy as 26\% of New Opponents Say Fukushima Drove Their Decision. 2011. URL: http://www. ipsos-na.com/news-polls/pressrelease. aspx?id=5265 (Letöltés dátuma: 2015. okt. 26.) 
Kleijnen, M. - Lee, N. - Wetzels, M.: An Exploration of Consumer Resistance to Innovation and Its Antecedents. In: Journal of Economic Psychology. 2009. 30 (3) 344-357.

Koppelmann, U. - Willers, C.: Gentechnik und Lebensmittel - Marketing in Widerstandsmärkten. In: Marketing Review St. Gallen. 2008. 25 (5) 40-45.

Kovács A.: Kommunikáció a társadalommal, mint atomenergia-fogyasztóval. Doktori értekezés. Pécs, PTE KTK Regionális Politika és Gazdaságtan Doktori Iskola, 2010.

László É. - Földi K.: „Máshol és másként” - változások a hazai lakosság élelmiszer vásárlási és fogyasztási szokásaiban. In: A válság hatása a kiskereskedelemre. (Szerk.: Sikos T. T.). Szent István Egyetemi Kiadó, Gödöllő, 2013, 91-100.

Lehota J. - Csíkné Mácsai É. - Rácz G.: $\mathrm{Az}$ egészségtudatos élelmiszerfogyasztói magatartás értelmezése a LOHAS koncepció alapján. In: Táplálkozásmarketing. The Hungarian Journal of Nutrition Marketing. 2014. 1 (1-2) 39-50.

London Greenpeace: Whats wrong with McDonald's? Factsheat. 1986. URL: http://www.mcspotlight.org/case/ pretrial/factsheet_new.html (Letöltés dátuma: 2015. okt. 20.)

Malhotra, N. K.: Marketingkutatás. Akadémiai Kiadó, Budapest, 2005.

Matolay R.: A biotechnológiai közösségek. Mühelytanulmányok, Budapesti Corvinus Egyetem Vállalatgazdaságtan Intézet. 2005. Nr. 69.

Neulinger, Á. - Simon, J.: Food consumption patterns and healthy eating across the household life cycle in Hungary. In: International Journal of Consumer Studies. 2011. 35 (5) 538-544.

Pellandini-Simányi, L.: Consumption Norms and Everyday Ethics. Palgrave Macmillan, New York, Basingstoke, 2014.

Ram, S.: A Model Of Innovation Resistance. In: Advances in Consumer Research. 1987. 14 (1) 208-212.
Ritzer, G.: The 'McDonaldization' of Society. In: Journal of American Culture. 1983. 6 (1) 100-107.

Rogers, E. M.: New Product Adoption and Diffusion. In: Journal of Consumer Research. 1976. 2 (4) 290-301.

Sassatelli, R. - Davolio, F.: Consumption, Pleasure and Politics: Slow Food and the politico-aesthetic problematization of food. In: Journal of Consumer Culture. 2010. 10 (2) 202-232.

Sheth, J. N.: Psychology of innovation resistance: the less developed concept (LDC) in diffusion research. In: Research in Marketing. 1981. 4 273-282.

Simon J.: A klaszterelemzés alkalmazási lehetőségei a marketingkutatásban. In: Statisztikai Szemle. 2006. 84 (7) 627-649.

Szakály, Z. - Balogh, P. - Jasák, H. Szabó, S. - Szente, V.: The Influence of Personal Values on the Transition towards Health-conscious Diet: a Segmentation Approach. In: Journal of Food And Nutrition Research. 2014. 2 (8) 476-484.

Szente V. - Szakály Z. - Széles Gy.: Ökoélelmiszerek megítélése Magyarországon - alakuló fogyasztói tudatosság? In: Gazdálkodás. 2011. 55 (5) 512-517.

Törőcsik M.: Fogyasztói magatartás. Insight, trendek, vásárlók. Akadémiai Kiadó, Budapest, 2011.

Törőcsik M. - Jakopánecz E.: A fogyasztói ellenállást kiváltó termékek - egy sajátos termékkategória. In: Marketing \& Menedzsment. The Hungarian Journal of Marketing and Management. 2010. 44 (2) 4-13.

Törőcsik M. - Jakopánecz E.: A fogyasztói félelem - kockázatészleléstőlazellenállásig. In: Felelős marketing: Marketing Oktatók Klubja XVII. Országos Konferenciája. (Szerk.: Fojtik J.). Pécsi Tudományegyetem Közgazdaságtudományi Kar, Pécs, 2011. aug. 29 - 2011. aug. 30., 13-21.

Törőcsik, M. - Jakopánecz, E. - Soós, J.: The category of products generating consumer resistance. In: 1oth International Marketing Trends Conference. [CD]. (Eds.: Andreani, J. - Collesei, C. U.). ESCP Europe, Paris, 2011. 9. 
Varga B. - Szilágyi R.: Kvantitatív információképzési technikák. Nemzeti Tankönyvkiadó, 2011.
Willers,

$$
\text { C.: }
$$$$
\text { Marketing }
$$

in

Widerstandsmärkten $\quad-\quad$ Untersucht am Beispiel gentechnisch veränderter Lebensmittel. Fördergesellschaft ProduktMarketing, Köln, 2007.

\section{JEGYZETEK * NOTES}


JEGYZETEK $\nRightarrow$ NOTES 